Journal An-Nafs: Kajian Penelitian Psikologi

https://ejournal.iai-tribakti.ac.id/index.php/psikologi

e-ISSN: 2549-6166

p-ISSN: 2528-0600

DOI: $10.33367 /$ psi.v5i1.948

Submitted: 2019-10-11

Revised : 2019-11-29

Accepted : 2019-12-03

Published: 2020-06-01

\title{
TINJAUAN SISTEMATIS: FAKTOR-FAKTOR GAYA ATRIBUSI PRESTASI AKADEMIK
}

\author{
Alto Kusumo Yondrian \\ alto.kusumo.yondrian-2019@psikologi.unair.ac.id \\ Universitas Airlangga Surabaya
}

\begin{abstract}
Attribution style is one of the most relevant concepts in predicting academic achievement. Various researches have tried to study the factors that influence the attribution style. Several factors such as gender, ethnicity, and social class have been widely discussed in scientific publications. However, since Bernard Weiner first developed attribution theory more than 40 years ago, there have been changes in a social condition that might have affected various attribution factors. This review aims to see the latest developments in the factors that influence the attribution of academic achievement. A systematic search of articles published in 3 English-language international publishers since 2010 identified a total of 6 studies, which included 132.293 students from various nations. An assessment that measured qualities of a research in 4 areas: research design, sampling, measurement, and analysis identified 3 highquality research and 3 moderate-quality research. The result shows that ethnic factors confirm the findings from previous studies. Researches on gender factors provide new insights regarding the attribution style of female students. Besides, new factors emerge, such as school stratification and the attribution style of parents over their life events.
\end{abstract}

Keywords: Attribution, Academic achievement, Factors of attribution style

\begin{abstract}
Abstrak
Gaya atribusi merupakan salah satu konsep yang paling relevan dalam memprediksi prestasi akademik. Berbagai penelitian berusaha untuk mempelajari faktor-faktor yang memengaruhi gaya atribusi. Beberapa faktor seperti gender, etnis, dan kelas sosial telah banyak dibahas dalam publikasi ilmiah. Akan tetapi, sejak Bernard Weiner pertama kali mengembangkan teori atribusi lebih dari 40 tahun lalu, telah terjadi perubahan kondisi sosial yang mungkin berdampak pada berbagai faktor atribusi. Tinjauan ini bertujuan untuk melihat perkembangan terbaru faktor-faktor yang mempengaruhi atribusi prestasi akademik. Pencarian sistematis artikel penelitian di 3 penerbit internasional berbahasa Inggris sejak 2010 mengidentifikasi 6 publikasi yang melibatkan 132.293 pelajar dari berbagai negara. Berdasarkan hasil asesmen kualitas penelitian pada 4 bidang, yaitu desain penelitian, sampling, pengukuran, dan analisis menyimpulkan bahwa tiga penelitian termasuk dalam kualitas tinggi dan tiga penelitian termasuk dalam kualitas sedang. Hasilnya, faktor etnis menegaskan temuan-temuan penelitian sebelumnya. Penelitian tentang faktor gender memberikan wawasan baru terkait gaya atribusi pelajar perempuan. Selain itu, faktor-faktor baru bermunculan, seperti stratifikasi sekolah dan gaya atribusi orang tua atas peristiwa hidupnya sendiri.
\end{abstract}

Kata Kunci: Atribusi, Prestasi akademik, Faktor gaya atribusi 


\section{PENDAHULUAN}

Pendidikan merupakan investasi terbaik untuk mendukung keberlangsungan hidup dan kesejahteraan manusia (UNICEF, 2015). Secara rata-rata, penambahan satu tahun pendidikan akan meningkatkan pendapatan individu sebesar 10\% (Bank, 2011). Kendati demikian, meskipun angka putus kuliah di Indonesia yang sebesar 3\% relatif kecil (Dikti, 2018), tingkat pengangguran lulusan universitas per Februari 2019 meningkat 25\% dibandingkan 2 (dua) tahun sebelumnya (Statistik, 2019). Oleh karena itu, keberhasilan pendidikan perlu diupayakan agar individu dapat meraih manfaat sebesar-besarnya dari pendidikan. Indikator keberhasilan akademik seperti Indeks Prestasi seringkali menentukan luasnya kesempatan yang dimiliki invidu setelah meninggalkan sebuah lembaga pendidikan. Mengingat pengaruhnya yang begitu besar, maka penting untuk memahami faktor-faktor yang menyebabkan variasi pada prestasi akademik.

Secara umum, keberhasilan akademik dicapai apabila individu mengarahkan perilakunya untuk menyelesaikan tugas-tugas akademik dengan standar yang tinggi (Singh, 2011). Dorongan yang mendasari individu untuk tetap mengarahkan perilakunya ke suatu tujuan disebut dengan motivasi. Motivasi pelajar juga ditentukan oleh sikapnya ketika menghadapi kegagalan dan kesuksesan dalam bidang akademik (Weiner, 1985).

Teori motivasi Weiner menyebutkan bahwa seseorang cenderung menggunakan penyebab-penyebab tertentu untuk menjelaskan berbagai persitiwa di hidupnya. Atribusi penyebab ini diikuti oleh respon emosi yang berdampak pada perilaku masa depannya (Seifert, 2004). Penyebab-penyebab tersebut dapat dikelompokkan menurut karakteristiknya ke dalam 3 (tiga) dimensi, yakni locus, apakah penyebab tersebut berasal dari dalam atau luar individu; controllability, apakah penyebab yang dimaksud dapat dikendalikan oleh individu; dan yang terakhir, stability, apakah penyebab tersebut bersifat menetap atau dapat berubah. 4 (empat) gaya atribusi yang umum digunakan untuk menjelaskan hasil akademik, yaitu usaha (internal, dapat dikendalikan, dan tidak stabil), kemampuan (internal, tidak dapat dikendalikan dan stabil), tingkat kesulitan tugas (eksternal, tidak dapat dikendalikan, stabil), dan keberuntungan (eksternal, tidak dapat dikendalikan, tidak stabil) (Weiner, 1985).

Individu yang memiliki gaya atribusi usaha menunjukkan motivasi dan perilaku meguasai keterampilan baru yang lebih tinggi dibandingkan gaya atribusi berkarakteristik stabil (Grant \& Dweck, 2003). Individu dengan gaya atribusi usaha mempunyai perasaan bersalah atas kegagalannya. Akan tetapi, kegagalan tersebut dilihat sebagai sesuatu yang dapat diperbaiki selama individu meningkatkan usahanya. Dengan demikian, motivasi akademik tetap terjaga dengan harapan indvidu akan meraih prestasi yang lebih baik pada 
masa depan. Sementara itu, menganggap kegagalan disebabkan oleh faktor yang tidak dapat dikendalikan, seperti kemampuan atau keberuntungan, akan menghambat motivasi dan pencapaian akademik seseorang (Weiner, 1985).

Gaya atribusi telah menjadi salah satu pendekatan yang paling relevan dalam menjelaskan perilaku akademik (Vicent et al., 2019). Mahasiswa sarjana dengan gaya atribusi internal dan stabil berisiko lebih tinggi mencatatkan prestasi akademik yang buruk (Peterson \& Barrett, 1987). Gaya atribusi juga memengaruhi keberhasilan mahasiswa doktor di Amerika Serikat dalam menyelesaikan studi (Gardner, 2009).

Seiring berkembangnya literatur ilmiah tentang gaya atribusi, sebuah teknik intervensi kemudian diciptakan untuk mengubah gaya atribusi maladaptif seseorang menjadi lebih adaptif. Intervensi ini disebut dengan attributional retraining (AR). Berbagai penelitian mendukung efektivitas AR tidak hanya untuk mengubah gaya atribusi, tetapi juga meningkatkan motivasi akademik, mengembangkan pola pikir adaptif, dan memfasilitasi hasil akademik yang lebih baik (Haynes, Daniels, Stupnisky, Perry, \& Hladkyj, 2008; Haynes, Ruthig, Perry, Stupnisky, \& Hall, 2006; Perry, Stupnisky, Hall, Chipperfield, \& Weiner, 2010). Kendati demikian, penelitian AR selanjutnya perlu mempertimbangkan variabel-variabel laten yang mungkin memoderatori efektivitasnya (Matteucci, 2017). Upaya ini perlu dilakukan mengingat penelitian AR sebelumnya seringkali dijalankan dalam laboratorium eksperimen bukan pada kondisi belajar alami (Chodkiewicz \& Boyle, 2014).

Penelitian-penelitian AR selama ini terbatas pada kelompok subjek menurut tingkat pendidikan, pada mahasiswa yang berisiko tinggi putus kuliah, atau menyasar hasil positif pada mata pelajaran khusus (Matteucci, 2017) . Padahal, studi terkait teori atribusi telah berusaha mencari faktor-faktor yang memengaruhi kecenderungan individu untuk memiliki gaya atribusi tertentu.

Faktor sosial seperti keluarga merupakan sumber atribusi lain yang patut dipertimbangkan (McClure et al., 2011). Faktor sosial dapat berperan sebagai agen yang membuat individu dalam kelompok tertentu memiliki gaya atribusi yang khas. Sebagai contoh, pelajar keturunan Asia di Amerika Serikat cenderung memiliki gaya atribusi maladaptif sekalipun mempunyai prestasi akademik terbaik dibandingkan kelompok etnis utama lainnya (Bankston \& Zhou, 2002). Selain itu, gender merupakan salah satu faktor sosial yang telah dipelajari secara ekstensif. Penelitian-penelitian sebelumnya menyebutkan perempuan lebih sering melihat kesuksesan akademiknya disebabkan oleh faktor eksternal ketimbang pria. Peran tradisional perempuan sebagai pengelola utama rumah tangga mendorongnya untuk lebih peka terhadap kehadiran dan kondisi orang lain. Harapan sosial inilah yang membentuk kecenderungan perempuan untuk lebih 
mempertimbangkan faktor eksternal dalam memahami peristiwa di sekitarnya (Yadav \& Mishra, 2017). Namun, seiring semakin meleburnya peran sosial laki-laki dan perempuan, tidak menutup kemungkinan gaya atribusi perempuan juga turut berubah. Faktor usia juga belum cukup dibahas dalam penelitian. Padahal, pemberian attributional retraining diyakini perlu disesuaikan dengan usia individu (Hassaskhah \& Vahabi, 2010).

Berangkat dari permasalahan ini, penulis tertarik untuk melakukan tinjauan sistematis publikasi ilmiah mengenai faktor-faktor gaya atribusi prestasi akademik selama 10 tahun terakhir. Penulis tertarik untuk memahami relevansi faktor-faktor yang telah diteliti selama ini, begitu juga dengan kemungkinan munculnya faktor-faktor baru yang memengaruhi gaya atribusi seseorang dalam menyikapi kesuksesan dan kegagalan di bidang akademik.

Tinjauan sistematis ini diharapkan dapat digunakan sebagai rujukan bagi peneliti yang hendak menguji efektivitas attributional retraining dengan melibatkan variabel kontrol maupun moderator. Faktor-faktor yang dikemukakan di tinjauan ini diharapkan dapat membantu peneliti dalam menentukan variabel-variabel tersebut. Tinjauan ini juga diharapkan berkontribusi pada penelitian-penelitian selanjutnya yang ingin memahami perkembangan faktor-faktor gaya atribusi terutama dalam bidang pendidikan.

\section{METODE}

Dalam mencari literatur ilmiah untuk ditinjau, penulis menggunakan 3 sumber internasional, yakni ScienceDirect (sciencedirect.com), Springer Link (link.springer.com), dan SAGE (journals.sagepub.com). Pencarian dilakukan sejak 16 September 2019 sampai dengan 29 September 2019 dengan memasukkan kata kunci "attribution" AND "education" AND "students". Dengan mengikuti alur Preferred Reporting Items for Systematic Review and Meta-Analyses (PRISMA), publikasi akan diseleksi dengan kriteria berikut: 1) penelitian yang mengkaji faktor-faktor gaya atribusi prestasi akademik pada pelajar, 2) Diterbitkan dalam 10 tahun terakhir (2009-2019), 3) penelitian empiris, baik kuantitatif maupun kualitatif, 4) full-text dapat diunduh. Dari 4 kriteria tersebut didapatkan 6 publikasi ilmiah dengan rincian 2 dari ScienceDirect, 3 dari Springer Link, dan 1 dari SAGE. 


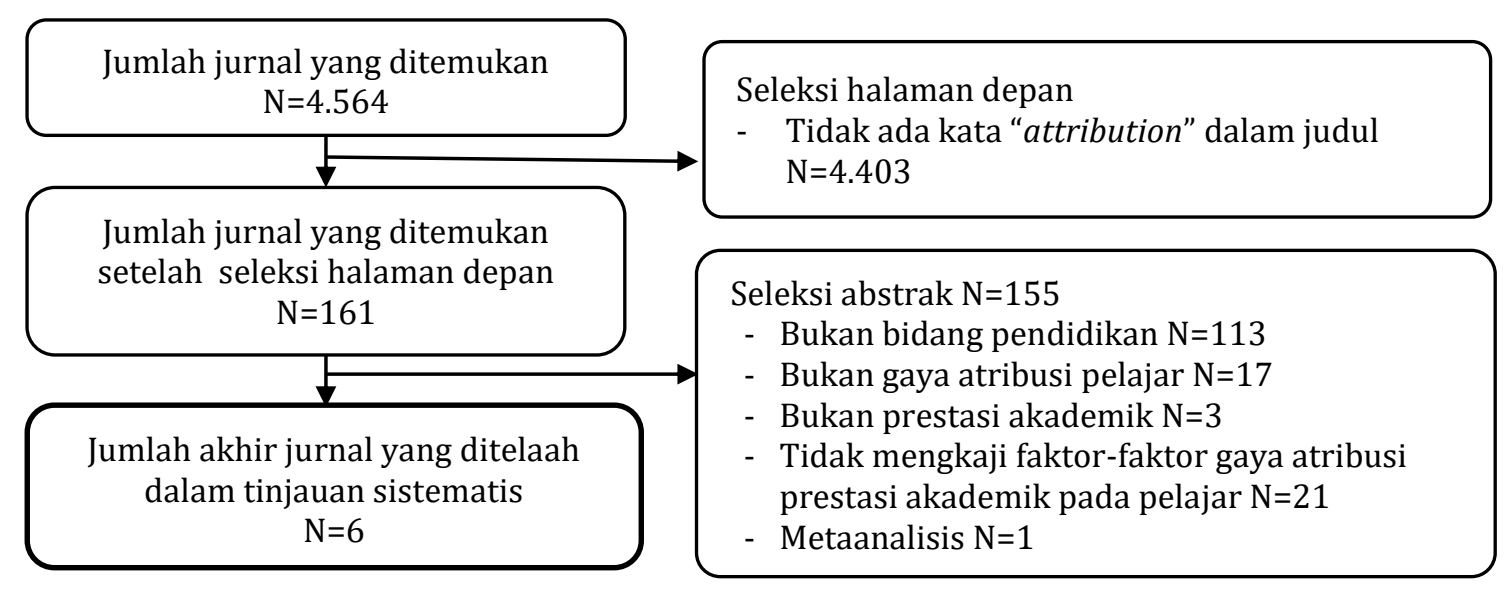

Gambar 1 Alur Seleksi Publikasi Ilmiah

\section{Asesmen Kualitas Penelitian}

Enam publikasi ilmiah yang disertakan dalam tinjuan sistematis ini kemudian dinilai kualitas metodologi penelitiannya. Kriteria penilaian terdiri dari 12 (dua belas) pertanyaan yang mencakup 4 (empat) bidang penelitian, yakni desain penelitian, sampling, pengukuran, dan analisis (Estabrooks et al., 2001). Setiap kriteria yang dapat dipenuhi mendapatkan skor 1 (satu). Dengan begitu, setiap penelitian dapat diketahui kualitas penelitiannya berdasarkan skor total yang diperoleh. Kategori kualitas penelitian dibagi menjadi 3 (tiga), yaitu rendah (0-3), sedang (4-8), dan tinggi (9-12). Berdasarkan asesmen kualitas yang telah dijalankan, 3 (tiga) penelitian termasuk dalam kualitas tinggi, dan 3 (penelitian) diketahui mempunyai kualitas sedang.

Dari keenam publikasi yang ditelaah, tidak ada satu penelitian yang mencantumkan prosedur penanganan data outlier dalam analisis statistiknya. Sementara itu, hanya satu penelitian yang menuliskan bahwa respon yang diberikan subjek penelitian bersifat anonim. Reliabilitas alat ukur juga menjadi kelemahan yang ditemukan pada 3 (tiga) penelitian. Ketiga penelitian yang dimaksud tidak mencantumkan internal consistency skala saat digunakan dalam penelitian atau memiliki nilai di bawah 0,70. Kelebihan dari 6 (enam) penelitian yang disertakan antara lain angka respon yang lebih dari 60\%, ukuran sampel yang memadai, serta penggunaan alat ukur yang didasarkan pada kerangka teori. Mengingat tidak ada penelitian yang berada pada kategori rendah, keenam publikasi ilmiah yang diniliai di tahap ini tetap dipertahankan ke tahap selanjutnya. 


\section{PAPARAN HASIL}

Berdasarkan prosedur seleksi yang telah dilakukan, terpilih 6 jurnal ilmiah untuk ditinjau lebih jauh. Hasil peninjauan terangkum dalam Tabel 1 di bawah ini:

Tabel 1 Ringkasan Jurnal Penelitian yang Ditinjau

\begin{tabular}{|c|c|c|c|c|c|}
\hline $\begin{array}{l}\text { Judul, } \\
\text { Penulis, } \\
\text { Tahun }\end{array}$ & $\begin{array}{c}\text { Lokasi } \\
\text { Penelitian }\end{array}$ & $\begin{array}{l}\text { Ukuran } \\
\text { Sampel }\end{array}$ & $\begin{array}{c}\text { Desain } \\
\text { Penelitian }\end{array}$ & $\begin{array}{c}\text { Instrumen } \\
\text { Pengukuran } \\
\text { Gaya } \\
\text { Atribusi }\end{array}$ & Temuan Utama \\
\hline $\begin{array}{l}\text { An in-depth } \\
\text { analysis of } \\
\text { the } \\
\text { relationship } \\
\text { between age } \\
\text { and } \\
\text { attribution in } \\
\text { EFL contexts } \\
\text { (Hassaskhah } \\
\text { \& Vahabi, } \\
\text { 2010) }\end{array}$ & $\begin{array}{l}\text { Lahijan, } \\
\text { Iran }\end{array}$ & $\begin{array}{l}\mathrm{n}=90 \\
\text { Demografi } \\
\text { sampel: } \\
30 \text { anak-anak } \\
\text { (6-12 tahun) } \\
30 \text { remaja } \\
(13-18 \\
\text { tahun) } \\
30 \text { dewasa } \\
\text { ( } \geq 19 \text { tahun) }\end{array}$ & Kuantitatif & $\begin{array}{l}\text { Instrumen } \\
\text { skala Likert } \\
\text { 5-poin yang } \\
\text { dibuat } \\
\text { mandiri } \\
\text { berdasarkan } \\
\text { teori atribusi } \\
\text { Weiner. } \\
\text { (Reliabilitas } \\
\text { instrumen } \\
\text { pengukuran= } \\
0,75 \text { ) }\end{array}$ & $\begin{array}{l}\text { Terdapat } \\
\text { perbedaan yang } \\
\text { signifikan pada } \\
\text { gaya atribusi di } \\
\text { berbagai } \\
\text { kelompok usia. } \\
\text { Anak-anak dan } \\
\text { dewasa memiliki } \\
\text { gaya atribusi } \\
\text { yang bersifat } \\
\text { tidak stabil dan } \\
\text { dapat } \\
\text { dikendalikan, } \\
\text { seperti usaha, } \\
\text { ketika } \\
\text { menghadapi } \\
\text { kegagalan. } \\
\text { Sementara } \\
\text { remaja } \\
\text { cenderung } \\
\text { mengatribusikan } \\
\text { pada tingkat } \\
\text { kesulitan tugas. }\end{array}$ \\
\hline $\begin{array}{l}\text { Doing better } \\
\text { but feeling } \\
\text { worse: an } \\
\text { attributional } \\
\text { account of } \\
\text { achievement } \\
\text { - self-esteem } \\
\text { disparities in } \\
\text { Asian } \\
\text { American } \\
\text { students } \\
\text { (Chen \& } \\
\text { Graham, } \\
\text { 2018) }\end{array}$ & $\begin{array}{l}\text { California, } \\
\text { Amerika } \\
\text { Serikat }\end{array}$ & $\begin{array}{l}\mathrm{n}=3.546 \\
\text { Demografi } \\
\text { Sampel: } \\
1.808 \\
\text { perempuan } \\
1.738 \text { laki- } \\
\text { laki } \\
\text { 43,8\% Latino } \\
26,0 \% \\
\text { Kaukasia } \\
\text { 16,4\% Asia } \\
\text { 13,8\% Afrika }\end{array}$ & Kuantitatif & $\begin{array}{l}\text { Kuesioner } 18 \\
\text { pertanyaan } \\
\text { untuk melihat } \\
\text { gaya atribusi } \\
\text { pelajar } \\
\text { menyikapi } \\
\text { kegagalan } \\
\text { selama di } \\
\text { sekolah } \\
\text { menengah. }\end{array}$ & $\begin{array}{l}\text { Pelajar } \\
\text { keturunan Asia } \\
\text { mempunyai self- } \\
\text { esteem yang } \\
\text { lebih rendah } \\
\text { akibat melihat } \\
\text { kegagalan } \\
\text { disebabkan oleh } \\
\text { rendahnya } \\
\text { kemampuan, } \\
\text { meskipun } \\
\text { mempunyai } \\
\text { prestasi } \\
\text { akademik } \\
\text { tertinggi } \\
\text { dibandingkan } \\
\text { kelompok etnis } \\
\text { lain. }\end{array}$ \\
\hline
\end{tabular}


Alto Kusumo Yondrian | Tinjauan Sistematis

\begin{tabular}{|c|c|c|c|c|c|}
\hline $\begin{array}{l}\text { Judul, } \\
\text { Penulis, } \\
\text { Tahun }\end{array}$ & $\begin{array}{c}\text { Lokasi } \\
\text { Penelitian }\end{array}$ & $\begin{array}{l}\text { Ukuran } \\
\text { Sampel }\end{array}$ & $\begin{array}{c}\text { Desain } \\
\text { Penelitian }\end{array}$ & $\begin{array}{c}\text { Instrumen } \\
\text { Pengukuran } \\
\text { Gaya } \\
\text { Atribusi }\end{array}$ & Temuan Utama \\
\hline $\begin{array}{l}\text { Gender- and } \\
\text { giftedness- } \\
\text { specific } \\
\text { differences in } \\
\text { mathematical } \\
\text { self-concepts, } \\
\text { attributions } \\
\text { and interests } \\
\text { (Benölken, } \\
\text { 2015) }\end{array}$ & $\begin{array}{l}\text { Munster, } \\
\text { Jerman }\end{array}$ & $\begin{array}{l}\mathrm{n}=288 \\
\text { Demografi } \\
\text { sampel: } \\
132 \\
\text { perempuan } \\
156 \text { laki-laki } \\
165 \text { tergolong } \\
\text { mathematical } \\
\text { ly gifted } \\
123 \text { tergolong } \\
\text { non- } \\
\text { mathematical } \\
\text { ly gifted }\end{array}$ & $\begin{array}{l}\text { Campuran } \\
\text { (Kuantitatif } \\
\text { dan } \\
\text { Kualitatif). } \\
\text { Data } \\
\text { Kualitatif } \\
\text { diambil dari } \\
\text { penelitian } \\
\text { penulis } \\
\text { sebelumnya } \\
\text {. }\end{array}$ & $\begin{array}{l}\text { Instrumen } \\
\text { yang } \\
\text { dikembangka } \\
\text { n sendiri } \\
\text { berdasarkan } \\
\text { teori atribusi } \\
\text { Weiner. }\end{array}$ & $\begin{array}{l}\text { Pelajar laki-laki } \\
\text { baik pada } \\
\text { kelompok } \\
\text { mathematically } \\
\text { gifted dan non- } \\
\text { mathematically } \\
\text { gifted cenderung } \\
\text { memiliki gaya } \\
\text { atribusi } \\
\text { fungsional } \\
\text { (internal dan } \\
\text { stabil untuk } \\
\text { kesuksesan, } \\
\text { eksternal dan } \\
\text { tidak stabil } \\
\text { untuk kegagalan) } \\
\text { dibandingkan } \\
\text { pelajar } \\
\text { perempuan non- } \\
\text { mathematically } \\
\text { gifted. }\end{array}$ \\
\hline $\begin{array}{l}\text { Personal and } \\
\text { Social Factors } \\
\text { in } \\
\text { Achievement- } \\
\text { Related } \\
\text { Cognition: A } \\
\text { Study of } \\
\text { Attribution, } \\
\text { Appraisal, } \\
\text { and Emotion } \\
\text { among } \\
\text { University } \\
\text { Students in } \\
\text { Delhi } \\
\text { (Yadav \& } \\
\text { Mishra, } \\
\text { 2017) }\end{array}$ & $\begin{array}{l}\text { New Delhi, } \\
\text { India }\end{array}$ & $\begin{array}{l}\mathrm{n}=80 \\
\text { Demografi } \\
\text { sampel: } \\
56 \\
\text { perempuan } \\
24 \text { laki-laki } \\
73,5 \% \\
\text { nuclear family } \\
26,25 \% \text { joint } \\
\text { family } \\
58,75 \% \text { Kelas } \\
\text { menengah } \\
30 \% \text { Kelas } \\
\text { menengah } \\
\text { bawah } \\
\text { 11,25\% Kelas } \\
\text { menengah } \\
\text { atas }\end{array}$ & Kuantitatif & $\begin{array}{l}\text { The Causal } \\
\text { Dimension } \\
\text { Scale } \\
\text { (Russell, } \\
\text { 1982). }\end{array}$ & $\begin{array}{l}\text { Mahasiswa dari } \\
\text { joint family } \\
\text { cenderung } \\
\text { mempunyai } \\
\text { atribusi internal } \\
\text { (kemampuan) } \\
\text { dalam menyikapi } \\
\text { kegagalan } \\
\text { dibandingkan } \\
\text { mahasiswa dari } \\
\text { nuclear family. } \\
\\
\text { Mahasiswa dari } \\
\text { kelas sosial atas } \\
\text { cenderung } \\
\text { mempunyai } \\
\text { atribusi internal } \\
\text { (usaha) dalam } \\
\text { menyikapi } \\
\text { kesuksesan. } \\
\text { Mahasiswa } \\
\text { perempuan } \\
\text { mempunyai } \\
\text { atribusi internal } \\
\text { terhadap } \\
\text { kesuksesan } \\
\text { dibandingkan } \\
\text { laki-laki. Begitu } \\
\text { juga dalam } \\
\text { melihat } \\
\text { penyebab suatu } \\
\text { kegagalan, }\end{array}$ \\
\hline
\end{tabular}


Alto Kusumo Yondrian | Tinjauan Sistematis

\begin{tabular}{|c|c|c|c|c|c|}
\hline $\begin{array}{l}\text { Judul, } \\
\text { Penulis, } \\
\text { Tahun }\end{array}$ & $\begin{array}{c}\text { Lokasi } \\
\text { Penelitian }\end{array}$ & $\begin{array}{l}\text { Ukuran } \\
\text { Sampel }\end{array}$ & $\begin{array}{c}\text { Desain } \\
\text { Penelitian }\end{array}$ & $\begin{array}{c}\text { Instrumen } \\
\text { Pengukuran } \\
\text { Gaya } \\
\text { Atribusi } \\
\end{array}$ & Temuan Utama \\
\hline & & & & & $\begin{array}{l}\text { perempuan } \\
\text { cenderung } \\
\text { memilih sumber } \\
\text { yang bersifat } \\
\text { tidak stabil } \\
\text { dibandingkan } \\
\text { laki-laki. }\end{array}$ \\
\hline $\begin{array}{l}\text { Relationships } \\
\text { of Parents' } \\
\text { and Child's } \\
\text { General } \\
\text { Attributional } \\
\text { Styles to } \\
\text { Academic } \\
\text { Performance } \\
\text { (Khodayarifa } \\
\text { rd, } \\
\text { Brinthaupt, \& } \\
\text { Anshel, 2010) }\end{array}$ & $\begin{array}{l}\text { New South } \\
\text { Wales, } \\
\text { Australia }\end{array}$ & $\mathrm{n}=179$ & Kuantitatif & $\begin{array}{l}\text { Gaya atribusi } \\
\text { pada anak- } \\
\text { anak: } \\
\text { Children's } \\
\text { Attributional } \\
\text { Style } \\
\text { Questionnair } \\
\text { e (CASQ; } \\
\text { Kaslow et al., } \\
\text { 1978). } \\
\text { (Reliabilitas } \\
\text { instrumen } \\
\text { pengukuran= } \\
\text { 0,67-0,71) } \\
\text { Gaya atribusi } \\
\text { pada orang } \\
\text { tua: } \\
\text { Attributional } \\
\text { Style } \\
\text { Questionnair } \\
\text { e } \\
\text { (ASQ; } \\
\text { Peterson et } \\
\text { al., 1982). } \\
\text { (Reliabilitas } \\
\text { instrumen } \\
\text { pengukuran= } \\
0,85-0,90 \text { ) }\end{array}$ & $\begin{array}{l}\text { Anak cenderung } \\
\text { memiliki gaya } \\
\text { atribusi yang } \\
\text { berbeda dengan } \\
\text { orang tuanya, } \\
\text { sedangkan } \\
\text { antara Ibu dan } \\
\text { Ayah cenderung } \\
\text { mempunyai gaya } \\
\text { atribusi yang } \\
\text { sama. } \\
\text { Gaya atribusi } \\
\text { anak, Ibu, dan } \\
\text { Ayah } \\
\text { berpengaruh } \\
\text { secara signifikan } \\
\text { pada prestasi } \\
\text { akademik anak. } \\
\text { Secara khusus, } \\
\text { semakin Ayah } \\
\text { mempunyai } \\
\text { atribusi internal } \\
\text { atas peristiwa } \\
\text { negatif dalam } \\
\text { hidupnya, } \\
\text { semakin tinggi } \\
\text { prestasi } \\
\text { akademik anak. }\end{array}$ \\
\hline $\begin{array}{l}\text { Stratified } \\
\text { Failure: } \\
\text { Educational } \\
\text { Stratification } \\
\text { and } \\
\text { Students'Attri } \\
\text { butions of } \\
\text { Their } \\
\text { Mathematics } \\
\text { Performance } \\
\text { in } 24 \\
\text { Countries } \\
\text { (Mijs, 2016) }\end{array}$ & $\begin{array}{l}\text { Data } \\
\text { diambil dari } \\
\text { laporan } \\
\text { Publication } \\
\text { of the } \\
\text { Programme } \\
\text { for } \\
\text { Internation } \\
\text { al Student } \\
\text { Assessment } \\
\text { (PISA) edisi } \\
\text { 2012. }\end{array}$ & $\mathrm{n}=128.110$ & Kuantitatif & $\begin{array}{l}\text { Programme } \\
\text { for } \\
\text { International } \\
\text { Student } \\
\text { Assessment's } \\
\text { Scale of } \\
\text { Students' } \\
\text { Attributions } \\
\text { of Failure in } \\
\text { Mathematics } \\
\text { (OECD, } \\
\text { 2014). }\end{array}$ & $\begin{array}{l}\text { Pelajar pada } \\
\text { sekolah } \\
\text { campuran } \\
\text { cenderung } \\
\text { melakukan } \\
\text { atribusi atas nilai } \\
\text { buruk } \\
\text { matematika pada } \\
\text { sumber } \\
\text { eksternal } \\
\text { dibandingkan } \\
\text { pelajar pada } \\
\text { sekolah vokasi } \\
\text { atau akademik. }\end{array}$ \\
\hline & & & & & $\begin{array}{l}\text { Perbedaan } \\
\text { antara gaya }\end{array}$ \\
\hline
\end{tabular}




\begin{tabular}{|c|c|c|c|c|c|}
\hline $\begin{array}{l}\text { Judul, } \\
\text { Penulis, } \\
\text { Tahun }\end{array}$ & $\begin{array}{c}\text { Lokasi } \\
\text { Penelitian }\end{array}$ & $\begin{array}{l}\text { Ukuran } \\
\text { Sampel }\end{array}$ & $\begin{array}{c}\text { Desain } \\
\text { Penelitian }\end{array}$ & $\begin{array}{c}\text { Instrumen } \\
\text { Pengukuran } \\
\text { Gaya } \\
\text { Atribusi }\end{array}$ & Temuan Utama \\
\hline & & & & & $\begin{array}{l}\text { atribusi pelajar } \\
\text { di sekolah } \\
\text { khusus dengan } \\
\text { campuran lebih } \\
\text { besar pada } \\
\text { negara di mana } \\
\text { sistem } \\
\text { stratifikasi lebih } \\
\text { ekstensif. }\end{array}$ \\
\hline & & & & & $\begin{array}{l}\text { Semakin } \\
\text { homogen status } \\
\text { sosioekonomi } \\
\text { suatu sekolah, } \\
\text { kecenderungan } \\
\text { para pelajarnya } \\
\text { untuk membuat } \\
\text { atribusi internal } \\
\text { atas kegagalan } \\
\text { semakin tinggi. }\end{array}$ \\
\hline
\end{tabular}

Setelah melakukan peninjauan mendalam terhadap publikasi terpilih, beberapa temuan terkait faktor-faktor yang berkontribusi pada gaya atribusi prestasi akademik pelajar dapat diringkas sebagaimana di bawah ini:

Tabel 2 Penjelasan Faktor-Faktor Gaya Atribusi

\begin{tabular}{|c|c|}
\hline $\begin{array}{c}\text { Faktor yang } \\
\text { Memengaruhi Gaya } \\
\text { Atribusi }\end{array}$ & Penjelasan tentang Faktor \\
\hline Etnis & $\begin{array}{l}\text { Pelajar etnis Asia di Amerika Serikat dibandingkan dengan etnis lain } \\
\text { (Latino, Afrika, dan Kaukasia), cenderung melihat penyebab } \\
\text { kegagalan dalam bidang akademik berasal dari faktor kemampuan } \\
\text { yang bersifat internal dan stabil. Gaya atribusi tersebut dapat } \\
\text { menurunkan motivasi berprestasi (Weiner, 1985). Namun, pada } \\
\text { kenyataannya gaya atribusi ini tidak berakibatlangsung pada prestasi } \\
\text { akademik, melainkan pada tingkat self-esteem. Hal inilah yang } \\
\text { menimbulkan paradoks pada pelajar etnis Asia di Amerika Serikat. } \\
\text { Meskipun prestasi akademik mereka relatif lebih baik, tingkat self- } \\
\text { esteem mereka yang terendah dibandingkan etnis lain (Chen \& } \\
\text { Graham, 2018). }\end{array}$ \\
\hline Gaya atribusi orang tua & $\begin{array}{l}\text { Bagaimana orang tua melihat penyebab peristiwa baik dan buruk } \\
\text { dalam hidupnya memengaruhi prestasi akademik anak. Anak yang } \\
\text { memiliki prestasi lebih baik cenderung mempunyai gaya atribusi } \\
\text { positif, yaitu menganggap kegagalan bersumber pada sesuatu yang } \\
\text { dapat dikendalikan dan tidak stabil seperti usaha, misalnya (Weiner, } \\
\text { 1985). Penelitian lain menunjukkan gaya atribusi Ayah lebih } \\
\text { menentukan gaya atribusi anak ketimbang pengaruh dari Ibu. Kendati } \\
\text { demikian, arah hubungan tersebut bersifat negatif. Artinya, anakyang } \\
\text { memiliki gaya atribusi positif untuk kegagalan, cenderung }\end{array}$ \\
\hline
\end{tabular}




\begin{tabular}{|c|c|}
\hline $\begin{array}{l}\text { Faktor yang } \\
\text { Memengaruhi Gaya } \\
\text { Atribusi }\end{array}$ & Penjelasan tentang Faktor \\
\hline & $\begin{array}{l}\text { mempunyai Ayah yang memiliki gaya atribusi negatif (internal dan } \\
\text { stabil, seperti kemampuan) untuk situasi yang sama (Khodayarifard } \\
\text { et al., 2010). }\end{array}$ \\
\hline Gender & $\begin{array}{l}\text { Perempuan cenderung mempunyai atribusi eksternal untuk } \\
\text { kesuksesan dan internal untuk kegagalan. Kombinasi tersebut } \\
\text { merupakan gaya atribusi yang kurang adaptif (Weiner, 1985). } \\
\text { Temuan itu bahkan berlaku pada kelompok anak berbakat. Namun, } \\
\text { perempuan mempunyai gaya atribusi yang lebih adaptif seiring } \\
\text { kesadaran akan potensinya meningkat. Hal ini ditunjukkan lewat } \\
\text { perubahan gaya atribusi ke bentuk yang lebih adaptif oleh seorang } \\
\text { siswi kelas } 8 \text { setelah dirinya bergabung dalam program khusus anak } \\
\text { berbakat (Benölken, 2015). Mahasiswi yang belajar di sebuah } \\
\text { universitas terkemuka bahkan memiliki gaya atribusi yang lebih } \\
\text { adaptif ketimbang mahasiswa laki-laki (Yadav \& Mishra, 2017). }\end{array}$ \\
\hline Kelas sosial & $\begin{array}{l}\text { Kelas atas cenderung memiliki atribusi internal dalam menyikapi } \\
\text { kesuksesan dibandingkan kelas sosial lainnya. Hal ini berkaitan } \\
\text { dengan ketersediaan material yang memungkinkan individu kelas } \\
\text { atas mengeksplorasi dan mengembangkan minat. Dengan demikian, } \\
\text { individu kelas atas mempunyai kendali lebih besar atas hidupnya. } \\
\text { Individu yang independen seperti itu cenderung melakukan atribusi } \\
\text { internal. Akan tetapi, individu kelas atas, dibandingkan kelas sosial } \\
\text { lain, juga cenderung melihat kesuksesannya disebabkan oleh } \\
\text { keberuntungan. Temuan ini menegaskan bahwa pada masyarakat } \\
\text { berbudaya kolektif, individu sangat mempertimbangkan faktor } \\
\text { eksternal dalam menjelaskan sebuah peristiwa (Yadav \& Mishra, } \\
\text { 2017). }\end{array}$ \\
\hline
\end{tabular}

Sistem Pendidikan Pelajar di sekolah dengan stratifikasi kemampuan (akademik atau vokasi) cenderung menyalahkan dirinya sendiri (internal) ketika mengalami kegagalan. Sebaliknya, pelajar di sekolah yang mengkombinasikan keduanya cenderung melakukan atribusi eksternal pada pendidik atau ketidakberuntungan. Temuan ini dikaitkan dengan teori heterogenitas dan homogenitas struktur sosial (Mijs, 2016). Di sekolah khusus akademik atau vokasi, faktor eksternal lebih seragam sehingga siswa cenderung membuat atribusi internal atas prestasi akademiknya. Di sekolah kombinasi, faktor eksternal lebih bervariasi sehingga siswa lebih mempertimbangkan penyebab-penyebab di luar dirinya dibandingkan siswa di sekolah khusus.

Struktur keluarga Perbedaan antara joint family dengan nuclear family terletak pada kehadiran keluarga lain di luar keluarga inti dalam satu rumah. Sebagai contoh, seorang cucu yang tinggal bersama orang tua dan kakek-neneknya termasuk joint family. Secara tradisional, pelajar yang berasal dari joint family dianggap lebih menyadari pengaruh orang lain dalam hidupnya. Oleh karena itu, mereka cenderung mengembangkan gaya atribusi eksternal. Mahasiswa yang berasal dari joint family justru menyikapi kegagalan dengan membuat atribusi internal (rendahnya kemampuan) dibandingkan mahasiswa dari nuclear family. Variasi interdependensi dalam joint family tampaknya lebih beragam dari yang diduga. Tidak hanya itu, status sebagai seorang mahasiswa membuat individu cenderung memandang penyebab kegagalan dan kesuksesannya bersumber 


\begin{tabular}{|c|c|}
\hline $\begin{array}{l}\text { Faktor yang } \\
\text { Memengaruhi Gaya } \\
\text { Atribusi }\end{array}$ & Penjelasan tentang Faktor \\
\hline & $\begin{array}{l}\text { pada faktor internal, seperti kemampuan atau usaha. Status ini } \\
\text { tampaknya lebih berpengaruh terlepas dari faktor eksternal (Yadav \& } \\
\text { Mishra, 2017). }\end{array}$ \\
\hline Usia & $\begin{array}{l}\text { Pada semua kelompok umur, usaha adalah faktor yang dianggap } \\
\text { paling siginifikan dalam kegagalan seseorang. Namun, setiap } \\
\text { kelompok umur mempunyai kecenderungan yang berbeda. Di antara } \\
\text { ketiga kelompok, anak-anak (6-12 tahun) mempunyai } \\
\text { kecenderungan paling tinggi untuk membuat atribusi usaha. } \\
\text { Kemudian diikuti dengan dewasa }(\geq 19 \text { tahun), dan yang terakhir } \\
\text { remaja (13-18 tahun) (Hassaskhah \& Vahabi, } 2010) \text {. }\end{array}$ \\
\hline
\end{tabular}

\section{PEMBAHASAN}

Setiap individu pada dasarnya selalu berusaha mencari penjelasan sebab-akibat atas peristiwa di dalam hidupnya, tidak terkecuali prestasi akademik selama proses pendidikan. Kecenderungan individu untuk melihat suatu peristiwa disebabkan oleh sumber tertentu disebut dengan gaya atribusi. Menurut teori atribusi, terdapat 4 gaya atribusi yang umum digunakan seseorang dalam menyikapi performa akademiknya, yaitu kemampuan (ability), usaha (effort), tingkat kesulitan tugas (difficulty of task), atau keberuntungan (luck) (Weiner, 1985). Gaya atribusi memengaruhi aspek kognitif dan afektif seseorang. Dampak dibentuknya gaya atribusi yang tidak adaptif oleh individu salah satunya akan menimbulkan efek negatif ketika mengalami kegagalan (Wilson, Damiani, \& Shelton, 2002). Apabila penyebab kegagalan tersebut juga dianggap berasal dari sesuatu yang tidak bisa dikendalikan, penurunan motivasi merupakan konsekuensi dari rangkaian afektif dan kognitif yang ada. Semakin rendah motivasi, individu cenderung mengarahkan perilakunya pada hal-hal yang menghindari penyelesaian masalah (Tsujimoto et al., 2018). Sebagai akibatnya, tidak ada peningkatan dalam prestasi akademik.

Berbagai penelitian menemukan pengaruh signifikan gaya atribusi terhadap prestasi akademik. Sebagai contoh, gaya atribusi memiliki dampak jangka panjang pada prestasi akademik (Hamm, Perry, Chipperfield, Murayama, \& Weiner, 2017); sedangkan di sebuah studi metaanalisis, kelompok yang diberikan intervensi modifikasi gaya atribusi menunjukkan nilai suatu mata kuliah 1 (satu) sampai dengan 2 (dua) kategori lebih baik daripada kelompok kontrol (Lazowski \& Hulleman, 2016). Salah satu kajian lain yang mendapatkan perhatian ilmiah adalah faktor-faktor yang menentukan gaya atribusi seseorang. Tinjauan sistematis ini bertujuan untuk melihat perkembangan faktor-faktor tersebut melalui penelitian yang dilakukan selama 10 tahun terakhir. Berdasarkan pencarian di empat basis data publikasi ilmiah, yakni Science Direct, Springer Link, SAGE, 
serta Garuda, tidak ditemukan tinjauan sistematis yang mengkaji faktor-faktor gaya atribusi dalam bidang pendidikan. Oleh karena itu, temuan secara keseluruhan pada penelitian ini tidak dapat dibandingkan dengan penelitian sebelumnya. Kendati demikian, pada bagian pembahasan ini, penelitian yang mewakili setiap faktor gaya atribusi dalam tinjauan sistematis akan dibandingkan dengan temuan pada peneltian-penelitian terdahulu.

Faktor-faktor gaya atribusi yang telah dibahas dalam tinjauan ini meliputi faktor sosial, seperti etnis, kelas sosial, gender, sistem pendidikan, dan keluarga; sementara usia mewakili faktor personal. Penelitian Chen dan Graham (2018) tentang pelajar keturunan Asia di Amerika Serikat mendukung temuan sebagian besar penelitian gaya atribusi dari sudut pandang etnis. Etnis Asia diketahui cenderung melakukan atribusi eksternal untuk kesuksesan dan atribusi internal untuk kegagalan (Lei, 2009). Keluarga Asia yang cenderung menganut budaya kolektivisme menenkankan pentingnya relasi dengan orang lain dalam menjalani hidup. Hal ini membuat orang Asia cenderung mempertimbangkan faktor eksternal saat menjelaskan hubungan sebab-akibat. Akan tetapi, orang Asia terutama dari bagian timur percaya bahwa kesuksesan dapat dicapai dengan pengembangan diri secara terus-menerus lewat kerja keras (Chen \& Graham, 2018). Dampak buruknya, sikap kritis yang berlebihan terhadap diri sendiri cenderung membentuk persepsi negatif tentang kemampuan individu (Hu, Zhang, \& Ran, 2016).

Faktor sosial lain yang telah dipelajari pengaruhnya terhadap gaya atribusi adalah kelas sosial. Perbedaan gaya atribusi di antara kelas sosial dipengaruhi oleh pengalaman pemenuhan kebutuhan hidup individu. Pada kelompok kelas bawah, karena keterbatasan sumber daya yang dimiliki, banyak peristiwa dalam hidup yang dianggap berada di luar kendalinya. Oleh karena itu, kelompok kelas bawah cenderung melihat faktor eksternal dalam menyikapi kegagalan dan kesuksesan pada bidang akademik. Kondisi sebaliknya dialami oleh kelompok kelas atas (Kraus, Piff, \& Keltner, 2011). Namun, mahasiswa dari kelompok kelas atas di India lebih sering menggunakan atribusi keberuntungan (eksternal, tidak dapat dikendalikan, tidak stabil) untuk kesuksesannya dibandingkan kelompok sosial lain. Temuan ini dijelaskan sebagai dampak dari budaya kolektivisme (Yadav \& Mishra, 2017).

Kelas sosial tetap berkaitan dengan gaya atribusi melalui faktor lain, yaitu sistem pendidikan. Pada negara yang menerapkan stratifikasi sekolah menurut keterampilan anak (vokasi dan akademik), komposisi sosioekonomi pelajar di suatu sekolah cenderung homogen. Pelajar di sekolah yang didominasi kelas sosial bawah dan etnis minoritas mungkin mengembangkan sikap inferior. Sikap tersebut berasal dari kepercayaan bahwa sistem pendidikan telah membatasi kesempatannya. Dengan demikian, individu merasa 
tidak memiliki kendali atas hidupnya (Agirdag, Van Houtte, \& Van Avermaet, 2012). Kendati demikian, penelitian lain menyebutkan pelajar di sekolah khusus, baik vokasi maupun akademik, cenderung memiliki gaya atribusi internal dalam melihat performa akademiknya (Mijs, 2016).

Dua penelitian tentang pengaruh gender dan keluarga menawarkan penjelasan terkini mengenai pola atribusi. Dalam berbagai penelitian, perempuan diketahui cenderung melakukan atribusi eksternal untuk kesuksesan dibandingkan laki-laki (Yadav \& Mishra, 2017). Perempuan juga cenderung melihat kesuksesan disebabkan oleh usaha daripada kemampuan dibandingkan laki-laki (McClure et al., 2011). Namun, perubahan atribusi kesuksesan dari eksternal ke internal pada perempuan tampaknya terbentuk apabila perempuan menyadari kemampuannya. Perubahan ini dijelaskan sebagai dampak diambilnya sampel penelitian di salah satu universitas terkemuka di India. Dapat diasumsikan, mahasiswa yang belajar di perguruan tinggi tersebut memiliki persepsi positif akan kemampuan akademiknya (Yadav \& Mishra, 2017). Penelitian lain juga mendukung argumen ini. Seorang anak perempuan mengubah gaya atribusinya ke internal setelah tanpa sengaja tergabung dalam program anak dengan kemampuan matematika istimewa (Benölken, 2015).

Mengenai faktor keluarga, penelitian selama ini seringkali berkutat pada kajian gaya atribusi orang tua terhadap prestasi akademik anak. Sebuah penelitian yang dilakukan di Australia ingin mengetahui pengaruh gaya atribusi orang tua atas peristiwa hidupnya sendiri terhadap gaya atribusi dan prestasi akademik anak. Hasilnya, gaya atribusi anak ternyata lebih dipengaruhi oleh gaya atribusi Ayah ketimbang Ibu. Sementara jika dihubungkan dengan prestasi akademik, gaya atribusi negatif Ayah justru diikuti dengan semakin tingginya prestasi anak (Khodayarifard et al., 2010).

\section{KESIMPULAN}

Berangkat dari tujuan tinjauan literatur ini, maka dapat disimpulkan penelitianpenelitian terkini tentang gaya atribusi mempunyai hasil yang beragam dalam kaitannya dengan penelitian-penelitian terdahulu. Penelitian faktor etnis yang dilakukan Chen dan Graham (2018) mengonfirmasi temuan sebelumnya tentang gaya atribusi orang Asia. Sedangkan penelitian Yadav dan Mishra (2017) serta Benölken (2015) memberi wawasan baru perihal dinamika gaya atribusi pada perempuan. Penelitian Hassaskhah dan Vahabi (2010) memperluas pemahaman faktor usia terhadap gaya atribusi akademik yang belum banyak dibahas. Adapun penelitian tentang pengaruh stratifikasi sekolah (Mijs, 2016) dan 
gaya atribusi orang tua atas peristiwa hidupnya sendiri (Khodayarifard et al., 2010), membuka kemungkinan munculnya faktor-faktor baru yang belum pernah dikaji selama ini.

\section{DAFTAR PUSTAKA}

Agirdag, O., Van Houtte, M., \& Van Avermaet, P. (2012). Why does the ethnic and socioeconomic composition of schools influence math achievement? the role of sense of futility and futility culture. European Sociological Review. https://doi.org/10.1093/esr/jcq070

Bank, W. (2011). World Development Report 2011: Conflict, Security, and Development. Washington, D.C.: The World Bank.

Bankston, C. L., \& Zhou, M. (2002). Being well vs. doing well: Self-esteem and school performance among immigrant and nonimmigrant racial and ethnic groups. International Migration Review. https://doi.org/10.1111/j.17477379.2002.tb00086.x

Benölken, R. (2015). Gender- and Giftedness-specific Differences in Mathematical Selfconcepts, Attributions and Interests. Procedia - Social and Behavioral Sciences, 174, 464-473. https://doi.org/10.1016/j.sbspro.2015.01.690

Chen, X., \& Graham, S. (2018). Doing better but feeling worse: an attributional account of achievement-self-esteem disparities in Asian American students. Social Psychology of Education, 21(4), 937-949. https://doi.org/10.1007/s11218-018-9447-9

Chodkiewicz, A. R., \& Boyle, C. (2014). Exploring the contribution of attribution retraining to student perceptions and the learning process. Educational Psychology in Practice, 30(1), 78-87. https://doi.org/10.1080/02667363.2014.880048

Dikti, K. (2018). Pusat Data dan Informasi Ilmu Pengetahuan, Teknologi, dan Pendidikan Tinggi. Retrieved from Statistik Pendidikan Tinggi 2018 website: https://pddikti.ristekdikti.go.id/asset/data/publikasi/Statistik\%25 20Pendidikan\%2520Tinggi\%2520Indonesia\%25202018.pdf

Gardner, S. K. (2009). Student and faculty attributions of attrition in high and lowcompleting doctoral programs in the United States. Higher Education. https://doi.org/10.1007/s10734-008-9184-7

Grant, H., \& Dweck, C. S. (2003). Clarifying Achievement Goals and Their Impact. Journal of Personality and Social Psychology. https://doi.org/10.1037/0022-3514.85.3.541

Hamm, J. M., Perry, R. P., Chipperfield, J. G., Murayama, K., \& Weiner, B. (2017). Attributionbased motivation treatment efficacy in an online learning environment for students who differ in cognitive elaboration. Motivation and Emotion, 41(5), 600-616. https://doi.org/10.1007/s11031-017-9632-8

Hassaskhah, J., \& Vahabi, M. (2010). An in-depth analysis of the relationship between age and attribution in EFL contexts. Procedia - Social and Behavioral Sciences, 5, 21262132. https://doi.org/10.1016/j.sbspro.2010.07.425 
Haynes, T. L., Daniels, L. M., Stupnisky, R. H., Perry, R. P., \& Hladkyj, S. (2008). The effect of attributional retraining on mastery and performance motivation among first-year college students. Basic and Applied Social Psychology. https://doi.org/10.1080/01973530802374972

Haynes, T. L., Ruthig, J. C., Perry, R. P., Stupnisky, R. H., \& Hall, N. C. (2006). Reducing the academic risks of over-optimism: The longitudinal effects of attributional retraining on cognition and achievement. Research in Higher Education. https://doi.org/10.1007/s11162-006-9014-7

Hu, T., Zhang, D., \& Ran, G. (2016). Self-serving attributional bias among Chinese adolescents. Personality and Individual Differences, 91, 80-83. https://doi.org/10.1016/j.paid.2015.10.008

Khodayarifard, M., Brinthaupt, T. M., \& Anshel, M. H. (2010). Relationships of parents' and child's general attributional styles to academic performance. Social Psychology of Education, 13(3), 351-365. https://doi.org/10.1007/s11218-010-9114-2

Kraus, M. W., Piff, P. K., \& Keltner, D. (2011). Social Class as Culture : The Convergence of Resources and Rank in the Social Realm Signals of Social Class: From Objective Resources to Cultural Symbols of Rank. Current Directions in Psychological Science. https://doi.org/10.1177/0963721411414654

Lazowski, R. A., \& Hulleman, C. S. (2016). Motivation Interventions in Education: A MetaAnalytic Review. Review of Educational Research. https://doi.org/10.3102/0034654315617832

Lei, C. (2009). On the Causal Attribution of Academic Achievement in College Students. Asian Social Science, 5(8), 87-96. https://doi.org/10.5539/ass.v5n8p87

Matteucci, M. C. (2017). Reconversion attributionnelle et buts d'accomplissement: une contribution exploratoire de leurs liens théoriques et empiriques. Revue Europeenne de Psychologie Appliquee, 67(5), 279-289. https://doi.org/10.1016/j.erap.2017.08.004

McClure, J., Meyer, L. H., Garisch, J., Fischer, R., Weir, K. F., \& Walkey, F. H. (2011). Students' attributions for their best and worst marks: Do they relate to achievement? $\begin{array}{llll}\text { Contemporary } \quad \text { Educational } & \text { 71-81. }\end{array}$ https://doi.org/10.1016/j.cedpsych.2010.11.001

Mijs, J. J. B. (2016). Stratified Failure: Educational Stratification and Students' Attributions of Their Mathematics Performance in 24 Countries. Sociology of Education, 89(2), 137-153. https://doi.org/10.1177/0038040716636434

Perry, R. P., Stupnisky, R. H., Hall, N. C., Chipperfield, J. G., \& Weiner, B. (2010). Bad starts and better finishes: Attributional retraining and initial performance in competitive achievement settings. Journal of Social and Clinical Psychology. https://doi.org/10.1521/jscp.2010.29.6.668

Peterson, C., \& Barrett, L. C. (1987). Explanatory Style and Academic Performance Among University Freshmen. Journal of Personality and Social Psychology. 
Alto Kusumo Yondrian | Tinjauan Sistematis

https://doi.org/10.1037/0022-3514.53.3.603

Seifert, T. L. (2004). Understanding student motivation. Educational Research, 46(2), 137149. https://doi.org/10.1080/0013188042000222421

Singh, K. (2011). Study of Achievement Motivation in Relation to Academic Achievement of Students. International Journal of Educational Planning \& Administration, 1(2), 161171. Retrieved from http://www.ripublication.com/ijepa.htm

Statistik, B. P. (2019). Berita Resmi Statistik. Retrieved May 6, 2019, from Badan Pusat Statistik website: https://www.bps.go.id/website/materi_ind/materiBrsInd20190506113732.pdf

Tsujimoto, K. C., Frijters, J. C., Boada, R., Gottwald, S., Hill, D., Jacobson, L. A., ... Gruen, J. R. (2018). Achievement attributions are associated with specific rather than general learning delays. Learning and Individual Differences, 64(March), 8-21. https://doi.org/10.1016/j.lindif.2018.04.002

UNICEF. (2015). The Investment Case for Education and Equity. New York, NY: United Nations Children's Fund.

Vicent, M., Inglés, C. J., Gonzálvez, C., Sanmartín, R., Aparicio-Flores, M. P., \& GarcíaFernández, J. M. (2019). Perfectionism Profiles and Academic Causal Selfattributions in Spanish Primary Education Students. Revista de Psicodidáctica (English Ed.), 24(2), 103-110. https://doi.org/10.1016/j.psicoe.2019.02.002

Weiner, B. (1985). An Attributional Theory of Achievement Motivation and Emotion. Psychological Review, 92(4), 548-573. https://doi.org/10.1037/0033295X.92.4.548

Wilson, T. D., Damiani, M., \& Shelton, N. (2002). Improving the Academic Performance of College Students with Brief Attributional Interventions. Improving Academic Achievement, (434), 89-108. https://doi.org/10.1016/b978-012064455-1/500087

Yadav, P., \& Mishra, A. K. (2017). Personal and Social Factors in Achievement-Related Cognition: A Study of Attribution, Appraisal, and Emotion among University Students in Delhi. Psychological Studies, 62(3), 291-304. https://doi.org/10.1007/s12646-017-0417-7 